\title{
Report of workshop "Violence, Security and Justice"
}

Synthèse de l'atelier "Violence, sécurité et justice"

\section{Stephen Ellis et Bayie Kamanda}

\section{OpenEdition}

\section{Journals}

Édition électronique

URL : http://journals.openedition.org/apad/170

DOI : 10.4000/apad. 170

ISSN : 1950-6929

Éditeur

LIT Verlag

Édition imprimée

Date de publication : 1 décembre 2002

Référence électronique

Stephen Ellis et Bayie Kamanda, «Report of workshop "Violence, Security and Justice" », Bulletin de I'APAD [En ligne], 23-24 | 2002, mis en ligne le 15 décembre 2006, consulté le 24 septembre 2020.

URL : http://journals.openedition.org/apad/170 ; DOI : https://doi.org/10.4000/apad.170

Ce document a été généré automatiquement le 24 septembre 2020.

Bulletin de l'APAD 


\title{
Report of workshop "Violence, Security and Justice"
}

Synthèse de l'atelier "Violence, sécurité et justice"

\author{
Stephen Ellis et Bayie Kamanda
}

\section{NOTE DE L'ÉDITEUR}

Reporter : Stephen Ellis. Discussant : Baye Kamanda

1 There were four papers presented in the session. A fifth paper was available but was neither presented nor discussed as the author was not present. There were some 18 people in attendance.

2 J.C. Bekker presented a paper on the administration of justice by traditional leaders in post-apartheid South Africa. During the twentieth century, successive governments incorporated traditional leaders into a system of indirect rule and created a body of statute law authorizing the exercise of judicial authority by chiefs or traditional leaders. This system still operates today in rural areas. It is notable that much of the object of judicial proceedings is not so much to identify and punish lawbreakers as to reconcile members of a community who are in some form of dispute.

3 Marks Chabedi also gave a paper on South Africa, this time on the urban environment of Soweto, the township outside Johannesburg that became world famous during the 1970s. The author presented a short history of Soweto from its creation and noted the problems of violence and insecurity that are common there today. The transition from apartheid in South Africa was more marked in the political sphere than in the social and economic realities of daily life.

4 Fatima Adamu's presentation was on sharia courts and Muslim women in northern Nigeria. Having briefly outlined the importance of Islam in the lives of women in northern Nigeria, she explained the history of the introduction of sharia after the return of civilian rule in 1999. It is striking that, before its formal introduction for use in criminal offences, sharia was often felt to offer particular protection to women, e.g. 
in cases of domestic disputes. Since its formalisation as state law, however, sharia seems increasingly to be taking the form of a repressive force as far as women are concerned, as witnessed by the well-known recent case of Safiya Husaini, the woman sentenced to death by stoning for adultery (but later acquitted on appeal).

5 Nkolika E. Obianyo's paper also concerned Nigeria. She described the rise in Anambra State of the civil vigilante movement known as the Bakassi Boys, now officially incorporated by the state government as the Anambra State Vigilante Services. The Bakassi Boys were introduced into Anambra State in the late 1990s as a result of the growth of armed robbery in particular, especially in the major market centre of Onitsha. The Bakassi Boys were at first very popular with market traders and the general public.

6 Since their reorganization as an official state paramilitary force, however, the Bakassi Boys have been increasingly used for political purposes. This has had a marked effect on the manner in which the $y$ are perceived by the general public.

7 The discussion was initiated by Bayie Kamanda, who is himself a traditional ruler as well as a sociologist. The four papers (plus a fifth by Julia Hornberger, on the police in South Africa) fitted together rather well, not least because they concerned just two countries. Speakers with knowledge of other parts of Africa were able to recognize the key elements from their own areas without difficulty. It was clear that in many parts of the continent, people have been obliged to develop techniques for self-protection or for the dispensation of some form of justice. There was some discussion of how this worked in rural areas where some form of "traditional" authority remains recognizably intact : it is hardly appropriate to speak of "tradition" in such cases as old forms of governance have typically been utterly transformed by colonial and postcolonial rule. Such authorities have shown a great capacity to absorb change. It does appear that the greatest vacuum in this respect tends to occur in urban areas, where there is little rooted form of traditional authority and where insecurity is sometimes acute.

There was discussion of different forms of informal security, ranging from customary forms to informal vigilantes and others. It is clear that this is in many respects a response to gross deficiencies in the legally constituted state. However, the villages and the cities are not two separate universes but are connected by the continuing links of urban people with their rural villages of origin, or the presence in villages of people who have retired after making their careers in town.

9 The phenomenon of informal justice and security is likely to remain both important and in need of study for the foreseeable future. It was noted that it represents a failure of politics in the sense of a system to negotiate personal and collective interests in public and to identify a common good. The depoliticisation of state governance has been encouraged by structural adjustment and the treatment of certain questions as technical matters to be resolved by experts in conclave rather than through public activity. The resulting development of intensely localized interests may not be a solution to the problem posed by the failure of general state institutions in these fields. 


\section{AUTEURS}

\section{STEPHEN ELLIS}

ASC, Leiden.

BAYIE KAMANDA

Univ. Yaoundé 1. BP 13179, Yaoundé, Cameroun ; congestion.iucn@camnet.cm 